\title{
EFFECT OF RESVERATROL ON GENOMIC STABILITY IN FANCONI ANEMIA
}

\author{
Peter S. Fahmy ${ }^{(1)}$; Mostafa H. Ragab ${ }^{(2)}$; Amal M. Mohamed ${ }^{(1)}$; \\ Maha M. Eid ${ }^{(1)}$ and Ghada Y. El-Kamah ${ }^{(1)}$ \\ 1) National Research Centre 2) Institute of Environmental Studies and Research, \\ Ain Shams University
}

\begin{abstract}
Fanconi anemia is a genetically and phenotypically heterogenous disorder characterized by DNA repair deficiency and telomeric erosion. Different antioxidants have been assessed to regain the chromosomal stability in Fanconi anemia, among those is the Resveratrol. In Vitro Micronucleus assay provides a convenient and reliable index of both chromosome breakage and chromosome loss assessment. This study aims to assess the effect of Resveratrol on the stability of the chromosomes in Fanconi anemia patients using in vitro micronucleus assay as a parameter of improvement. The present study was conducted on 10 patients and 10 normal controls matching in age and sex. Induction of breakage by 1,3-Butadiene diepoxide and evaluation of the antioxidant effect of Resveratrol on genomic stability using In Vitro Micronucleus assay technique were done. Significant reduction in the level of micronuclei in cultures treated with Resveratrol was found. Resveratrol could be an effective adjuvant therapy for patients with FA to improve their hematological condition, chromosomal stability and it might protect from cancer development.
\end{abstract}

Keywords: Fanconi anemia - Resveratrol - Micronuclei - Genomic stability

\section{INTRODUCTION}

Fanconi anemia (FA) is a genetically and phenotypically heterogenous disorder which is characterized by congenital malformations, progressive bone marrow failure, and predisposition to cancer, specially the hematological 
malignancies and solid tumors of the head and neck. FA is characterized by DNA repair deficiency and telomeric erosion, which finally lead to cell apoptosis. Telomeric shortening could be a result of chromosomal breakage or as a defect in the telomerase expression, (Popp et al., 2018).

FA affects approximately 1 in 100,000 live births. The average life expectancy is about 20 years. Hematopoietic progenitor cells in FA are genetically unstable, leading eventually to bone marrow failure, which is the main life-threatening problem in these patients. This defect also predisposes individuals to an increased frequency of clonal cytogenetics abnormalities, myelodysplastic syndrome (MDS) and acute leukemia. (Auerbach AD, 2015)

FA results from pathogenic variants in at least twenty-two genes, causing genomic instability. Twenty-two unique genes involved in crosslink repair are FANCA, FANCB, FANCC, FANCD1/BRCA2, FANCD2, FANCE, FANCF, FANCG, FANCI, FANCJ/BRIP1, FANCL, FANCM, FANCN/PALB2, FANCO/RAD51C, FANCP/SLX4, FANCQ/ERCC4, FANCR, FANCS, FANCT, FANCU, FANCV and FANCW. These genes had been identified and additional genes with pathogenic variants of FA or FA-like patients remain to be found. The detection of the gene affected by molecular methods is very important for providing the proper genetic counseling regarding the cancer risk and for individualizing the proper treatment for the patient. (Popp et al., 2018)

Cells from FA patients are hypersensitive to DNA cross-linking agents and they show multiple spontaneous and induced chromosome breakage, increased micronucleus formation and accelerated telomere shortening-(Grillari et al., 2007). Because hypersensitivity to the clastogenic (chromosome-breaking) effect of DNA-crosslinking agents provides a unique marker for the diagnosis of 
FA, this cellular characteristic is utilized as a diagnostic test for Fanconi anemia and to identify the pre-anemic patients, it also differentiates between patients with Fanconi anemia and aplastic anemia. A variety of chemical agents can be used to test for DNA crosslink sensitivity, among them the Diepoxybutane (DEB; 1,3-butadiene diepoxide). (Auerbach, 2015)

Different antioxidants have been assessed to regain the chromosomal stability in Fanconi anemia. The best used is a natural extracted antioxidant because of the low side effects. Among those is the Resveratrol, a polyphenol contained in grape skins, which can be used in the treatment of aging cells to keep their potency to proliferate and differentiate. (Uchiumi et al., 2011)

Resveratrol stimulates glutathione synthesis and reduces the generation of reactive oxygen species (ROS) in cultured human cells. These properties combine to retard the rate of cellular senescence, reduce telomere attrition, decrease oxidative damage to DNA, upregulation of DNA repair enzymes and increase number of cell divisions before becoming senescent. (Glade \& Meguid, 2015)

Micronuclei $(\mathrm{MNi})$ are expressed in dividing cells that either contain chromosome breaks lacking centromeres (acentric fragments) and/or whole chromosomes that are unable to travel to the spindle poles during mitosis. $\mathrm{MNi}$ provide a convenient and reliable index of both chromosome breakage and chromosome loss. Because $\mathrm{MNi}$ are expressed in cells that have completed nuclear division they are ideally scored in the binucleated stage of the cell cycle. In Vitro Micronucleus assay will be used in this study to assess the effect of 
Resveratrol on reduction of its formation as they are one of the causative agents in cell apoptosis. (Fenech, 2000)

\begin{abstract}
AIM OF THE STUDY
Assessment of the effect of Resveratrol on the stability of the chromosomes in Fanconi anemia patients using in vitro micronucleus assay as a parameter of improvement.
\end{abstract}

\title{
MATERIALS AND METHODS
}

The present study was conducted on 10 patients and 10 normal controls matching in age and sex. The patients were referred from the Hereditary Blood Disorders and Genodermatoses Clinics, National Research Centre (NRC), diagnosed clinically as Fanconi anemia. The controls were chosen matching in age and sex from the healthy brothers and sisters of the patients presented in the Human Genetics Clinic, National Research Centre (NRC).

The study was approved and carried out according to the recommendations of the Medical Research Ethics Committee. Patients and controls attending corresponding clinics were approached consecutively and an informed consent was obtained from patients and/or their legal guardians.

On the first visit a full clinical history was obtained including a threegeneration pedigree analysis, and family history followed by thorough clinical examination and diagnosis. Peripheral blood samples $(3 \mathrm{ml})$ were obtained for laboratory analysis. These samples were used for induction of breakage and In Vitro Micronucleus assay techniques. 
Induction of Breakage by 1,3-Butadiene diepoxide (DEB): The technique was done according to Auerbach (1993). For each case, at least 25 metaphases are scored. The case is considered positive if the characteristic isochromatid exchange figures are present.

Evaluation of the Antioxidant effect of Resveratrol on genomic stability using In Vitro Micronucleus assay technique:

For each patient and control, two peripheral blood lymphocytes cultures were done; one with $50 \mu \mathrm{g} / \mathrm{ml}$ pure Resveratrol solutions (Sigma) added with the culture and the other without the Resveratrol solution. Cytokinesis-block micronucleus cyto-assay was used on both cultured lymphocytes to detect the effect of Resveratrol on genomic instability, in which scoring is specifically restricted to once-divided binucleated $(\mathrm{BN})$ cells, which are the cells that can express MNi. The technique was done according to Garriott et al. (2002).

For every Case, 2 slides were prepared, one slide from each culture tube (one culture tube with Resveratrol and the other without Resveratrol). An average of 1000 binucleated cells with intact cell membrane were scored for MNi.

\section{RESULTS AND DISCUSSION}

Table 1: Clinical description of the Fanconi anemia patients

\begin{tabular}{|c|c|c|}
\hline & No. & \% \\
\hline \hline Café au lait patches & 1 & $10 \%$ \\
\hline Radial affection & 3 & $30 \%$ \\
\hline Low birth weight & 10 & $100 \%$ \\
\hline Microcephaly & 9 & $90 \%$ \\
\hline Stature & 7 & $70 \%$ \\
\hline Genital affection & 1 & $10 \%$ \\
\hline Pancytopenia & 10 & $100 \%$ \\
\hline
\end{tabular}


Table 2: Level of micronuclei in Fanconi patients compared to control group:

\begin{tabular}{|c|c|c|c|c|}
\hline & $\begin{array}{l}\text { MNi without } \\
\text { Resveratrol }\end{array}$ & MNi with Resveratrol & $\begin{array}{l}\text { T- } \\
\text { test }\end{array}$ & P value \\
\hline $\begin{array}{c}\text { Fanconi } \\
\text { anemia } \\
\text { (FA) }\end{array}$ & $\begin{array}{llr}\text { Mean: } 19.7 \quad / \quad 1000 \\
\text { studied cells } \\
\text { Range: } 10-36 \text { (Median } \\
\text { 20) }\end{array}$ & $\begin{array}{l}\text { Mean: } 0.8 / 1000 \text { studied } \\
\text { cells } \\
\text { Range: } 0-3 \text { (Median } \\
\text { Zero) }\end{array}$ & 2.26 & 0.0000718 \\
\hline $\begin{array}{l}\text { Normal } \\
\text { controls }\end{array}$ & $\begin{array}{l}\text { Mean: } 5 \text { / } 1000 \text { studied } \\
\text { cells } \\
\text { Range: } 0-8 \text { (Median } \\
\text { Zero) }\end{array}$ & $\begin{array}{l}\text { Mean: Zero } \\
\text { Range: Zero }\end{array}$ & 2.31 & 0.013 \\
\hline
\end{tabular}

The current study included 10 patients with FA, six males and four females; their ages ranged from 3 to 10 years. The $\mathrm{CBC}$ results of the patients showed that all patients were suffering from pancytopenia.

The level of micronuclei in Fanconi anemia is much higher than that of the control group regarding the culture without treatment. The cytogenetic results were promising in terms of the antioxidant effect of Resveratrol as the reduced level of micronuclei in cultures treated with Resveratrol was significant. The MNi average levels in cultures of FA patients without the addition of Resveratrol was 19.7 / 1000 studied cells, which turned to be 0.8 / 1000 studied cells in cultures with Resveratrol treatment. Also, Resveratrol affected the cultures of normal control group to reduce their average levels from 5 / 1000 studied cells in untreated cultures to zero in treated cultures. T-test: Paired two samples for means was done and it revealed t-Test $=2.26$ and $p$-value 0.0000718 which is statistically significant. That is to say that the presence of Resveratrol in the culture had improved the genomic instability and the formation of $\mathrm{MNi}$ in the cultured lymphocytes of the Fanconi anemia patients. 
J. Environ. Sci.

Institute of Environmental Studies and Research - Ain Shams University

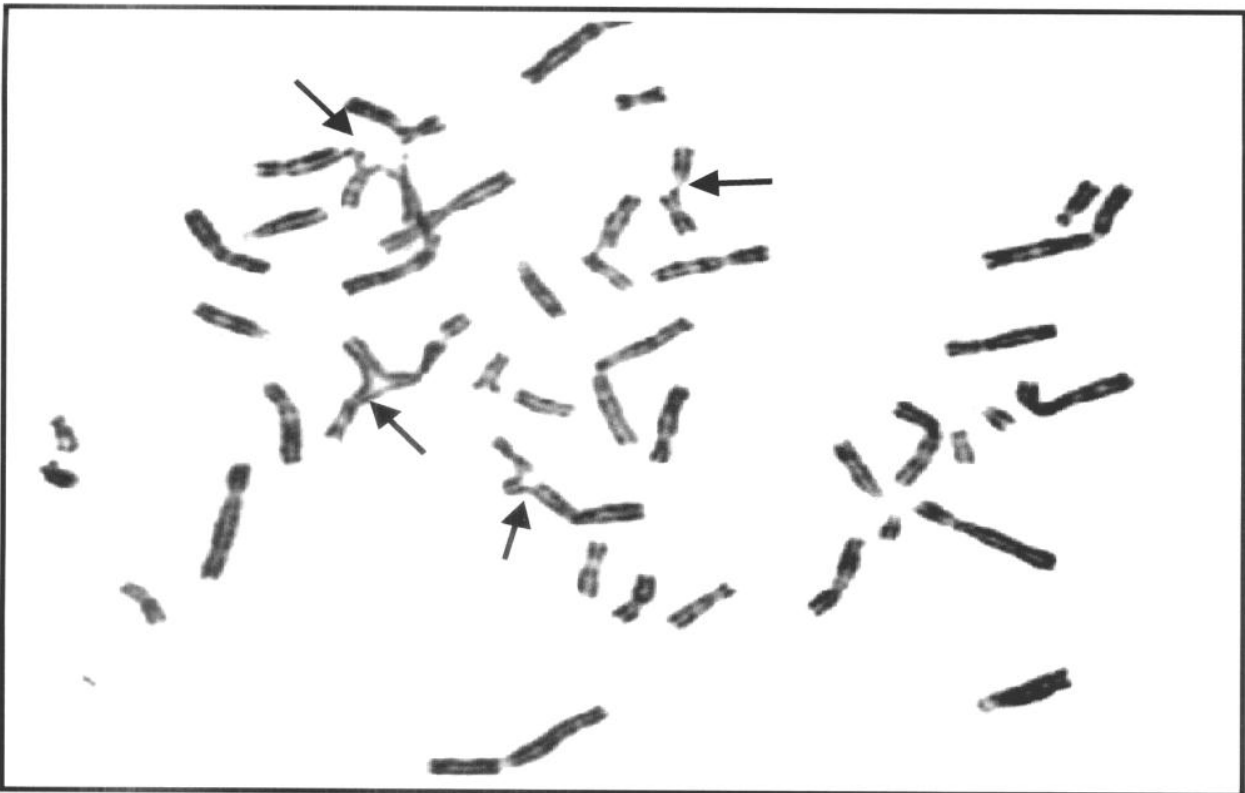

Figure 1: Metaphase spread showing multiple breaks and the triradial configuration

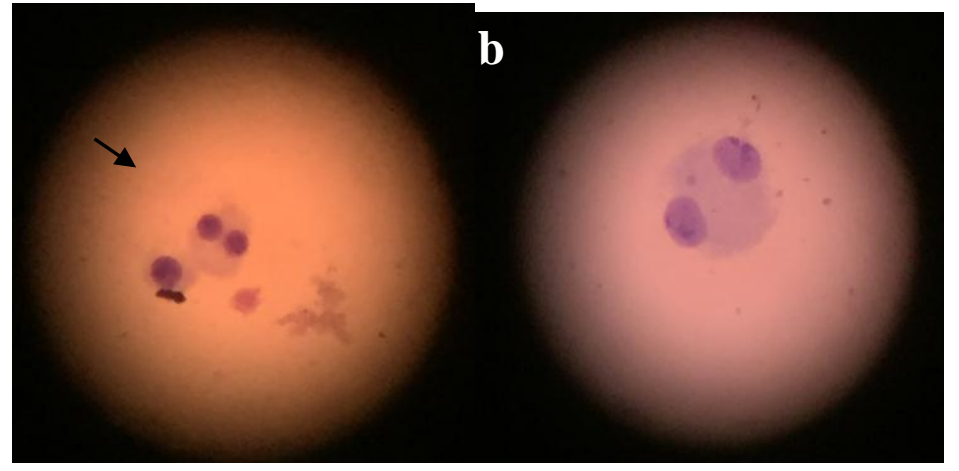

Figure 2: (a) One binucleated cell with one micronucleus in cultured blood lymphocytes without treatment. (b) One mononucleated and one binucleated cells without micronuclei in cultured blood lymphocytes after the addition of Resveratrol. 
FA is a disorder which is characterized by DNA repair defect, chromosomal aberrations and cancer susceptibility. FA patients have shown an abnormal reaction to oxidative stress, therefore, understanding the relationship between oxidative stress and disease progression is very important.

The current study included 10 patients with FA and their ages ranged from 3 to 10 years, while Eid et al. (2011) study included 12 patients with FA and their ages ranged from 2 to 25 years.

The CBC results of the patients in this study showed that all patients were suffering from pancytopenia, which was similar to other studies working on same age group with the same disease severity (Eid et al., 2011). The ages of these patients and their $\mathrm{CBC}$ profile might indicate their clinical condition stability probably because of the medical treatment and care given to them.

The results of in vitro micronucleus assay technique revealed that the $\mathrm{MNi}$ average levels in FA patients was 19.7 / 1000 studies cells, which in comparison to Eid et al. (2011) was 25.3 / 1000 studies cells. The high incidence of the MNi in FA patients could be due to the increased chromosomal breakage and/or chromosomal loss. Also, the high frequency of MNi in FA patients could be attributed to the unrepaired chromosomal breaks, DNA misrepair and the telomeric breakages, which were reported previously in other studies (Callén et al., 2002; Donahue and Campbell, 2002). Also the difference in the average level of MNi may be due to the diverse severity of clinical condition and pancytopenia found in FA patients.

The Effect of Resveratrol as a potent antioxidant was statistically significant, as it reduced the frequency of MNi in cultures to the level of zero. Also, Resveratrol affected the cultures of normal control group to reduce their 
average levels from 5 / 1000 studied cells in untreated cultures to zero in treated cultures. This effect of Resveratrol could be compared to other antioxidants as Astaxanthin - bioactive natural carotenoid - which decreases the level of induction of breakage by DEB in FA patients (Capelli and Cysewski, 2007; Eid et al., 2013). In this study it was found that the Resveratrol has effect on correction of genomic damage, this encourage the application of the in vitro test on large number of patient's samples with different concentrations of Resveratrol. This may help to reach to the safe dose for in vivo dosage and its use as an antioxidant and correction of genome damage in Fanconi anemia patients.

\section{CONCLUSION}

It is known that genetic susceptibility to cancer development is related to genomic instability, thus, the micronucleus assay could be used as a biomarker for assessment of the progress of the FA disease.

Also, from the present study, it is evident that Resveratrol is a potent antioxidant with the ability to reduce genomic instability (in vitro) in patients with FA. Resveratrol could be an effective adjuvant therapy for patients with FA to improve their pro-oxidant status, thus improves their hematological condition; also, by improving the chromosomal stability, it might protect FA patients from cancer development.

\section{REFERENCES}

Auerbach, A.D. (1993): Fanconi anemia diagnosis and the diepoxybutane (DEB) test. Exp Hematol. Jun;21(6):731-3.

Auerbach, A.D. (2015): Diagnosis of Fanconi Anemia by Diepoxybutane Analysis. Current protocols in Human Genetics. April;85(1):1-17. 
Callén, E; Samper, E; Ramirez, M.J; Creus, A; Marcos, R; Ortega, J.J. (2002): Breaks at telomeres and TRF2-independent end fusions in Fanconi anemia. Hum Mol Genet. 11:439-444.

Capelli, B; Cysewski, G. (2007): Natural astaxanthin: king of the carotenoids. Kailua-Kona, Hawaii, USA: Cyanotech Corporation; 2007.

Donahue, S.L; Campbell, C. (2002): A DNA double strand break repair defect in a biomarker for assessment of the progress of the disease. $J$ Biol Chem. 277:46243-46247.

Eid, M; Temtamy, S; El-Kamah, G; Eid, O. (2011): Cytokinesis-blocked micronucleus assay in a group of Egyptian patients with Fanconi anemia. Middle East J Med Genet.2090-8571.

Eid, M; Temtamy, S; Soliman, E; Shehab, M; et al. (2013): Evaluation of the invitro protective effect of plant extract (astaxanthin) on chromosomal breakage in Fanconi anemia cell culture. Middle East J Med Genet. $2: 45-49$.

Fenech, M. (2000): The in vitro micronucleus technique. Mutation Research 455:81-95.

Fenech, M. (2007): Cytokinesis-block micronucleus cytome assay. Nature Protocols. 2:1084-1104.

Garriott, M; Phelps, J; Hoffman, W. (2002): A protocol for the in vitro micronucleus test: Contributions to the development of a protocol suitable for regulatory submissions from an examination of 16 chemicals with different mechanisms of action and different levels of activity. Mutation Research. 517:123-134.

Glade, M; Meguid, M. (2015): A glance at ... telomeres, oxidative stress, antioxidants, and biological aging. Nutrition Kidlington. 31:11-12.

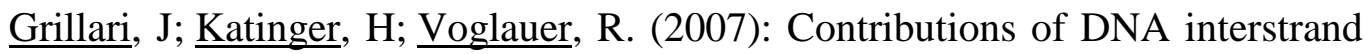
cross-links to aging of cells and organisms. Nucleic Acids Research. 35(22):7566-7576.

Popp, I; Punekar, M; Telford, N; Stivaros, S; Chandler, K. et al. (2018): Fanconi anemia with sun-sensitivity caused by a Xeroderma pigmentosumassociated missense mutation in XPF. BMC Medical Genetics. 19:7. 
Uchiumia, F; Watanabea, T; Hasegawaa, S; Hoshia, T; Higamib, Y; Tanumac, S. (2011): The Effect of Resveratrol on the Werner Syndrome RecQ Helicase Gene and Telomerase Activity. Current Aging Science. 4:1-

7.

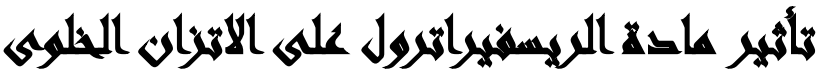

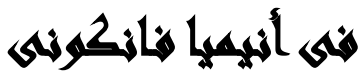

$[r]$

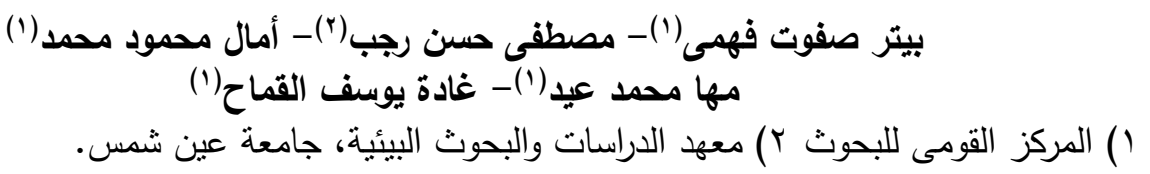

\section{المستخليى}

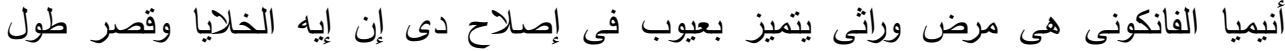

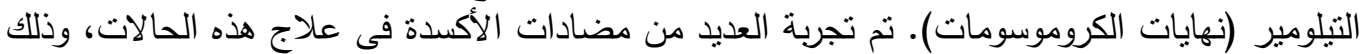

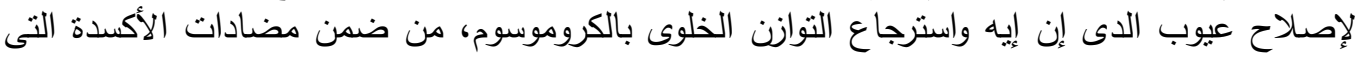

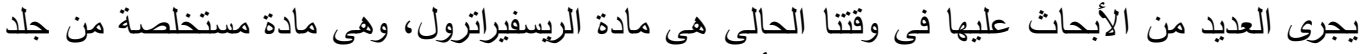
العنب الأحمر • اهدف هذا البحث لدراسة تأثنير مادة الريسفيراترول على إستقرار الكروموسومات فى

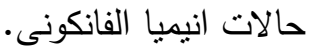
تمت الدراسة على عشرة حالات انيميا الفانكونى من المترددين على عيادة امراض الدم والجلد

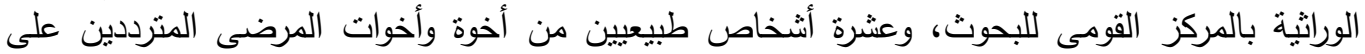

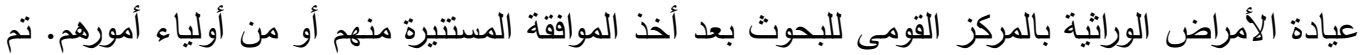

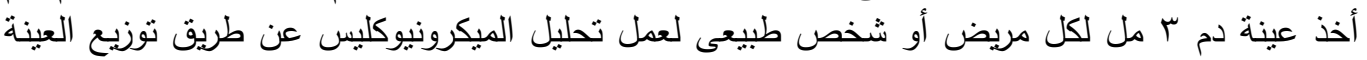

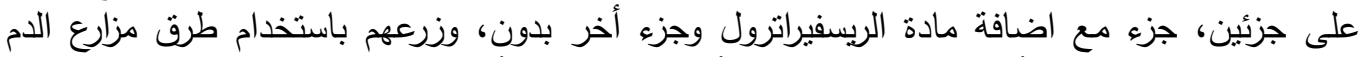

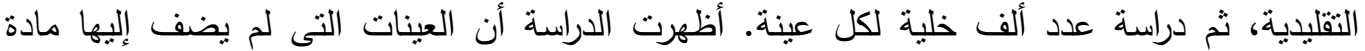

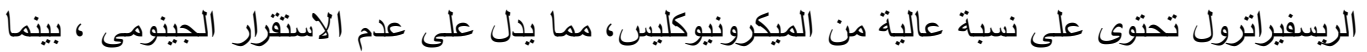

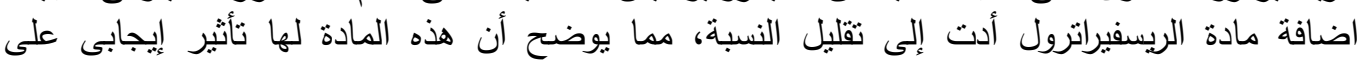

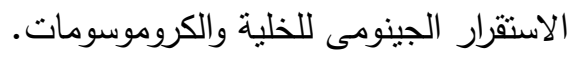

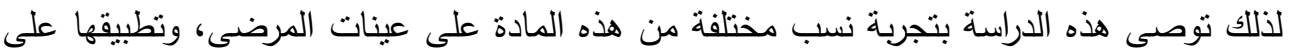
الأمراض المختلفة التى تتميز بعدم الاستقرار الجينومى للخلايا، كما توصى الدراسة باستخدام هذه المادة 
كجزء تكميلى لعلاج مرض انيميا الفانكونى مما قد يؤدى الى تحسن حالتهم الصحية وحمايتهم من مرض

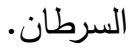
الكلمات الدالة: أنيميا فانكونى - ريسفيراترول - مايكرونيوكليس - الاستقرار الجينومى 